NBER WORKING PAPER SERIES

\title{
COMMODITY PRICE VOLATILITY AND WORLD MARKET INTEGRATION
} SINCE 1700

David S. Jacks

Kevin H. O'Rourke

Jeffrey G. Williamson

Working Paper 14748

http://www.nber.org/papers/w14748

\author{
NATIONAL BUREAU OF ECONOMIC RESEARCH \\ 1050 Massachusetts Avenue \\ Cambridge, MA 02138 \\ February 2009
}

We acknowledge with thanks help rendered by Sambit Bhattacharyya, Chris Blattman, George Boyer, Luis Catão, Bob Gregory, Jason Hwang, Norman Loayza, Alan Matthews and Steve Poelhekke, although they are not responsible for any flaws that may remain. Much of the work on this paper took place while O'Rourke was a Government of Ireland Senior Research Fellow, and he thanks the Irish Research Council for the Humanities and Social Sciences for their generous support. Williamson does the same for the Harvard Faculty of Arts and Science. Jacks gratefully acknowledges the Social Sciences and Humanities Research Council of Canada for research support. The views expressed herein are those of the author(s) and do not necessarily reflect the views of the National Bureau of Economic Research.

NBER working papers are circulated for discussion and comment purposes. They have not been peerreviewed or been subject to the review by the NBER Board of Directors that accompanies official NBER publications.

(C) 2009 by David S. Jacks, Kevin H. O'Rourke, and Jeffrey G. Williamson. All rights reserved. Short sections of text, not to exceed two paragraphs, may be quoted without explicit permission provided that full credit, including $(\mathrm{C}$ notice, is given to the source. 
Commodity Price Volatility and World Market Integration since 1700

David S. Jacks, Kevin H. O'Rourke, and Jeffrey G. Williamson

NBER Working Paper No. 14748

February 2009

JEL No. F14,N7,O19

\begin{abstract}
$\underline{\text { ABSTRACT }}$
Poor countries are more volatile than rich countries, and we know this volatility impedes their growth. We also know that commodity price volatility is a key source of those shocks. This paper explores commodity and manufactures price over the past three centuries to answer three questions: Has commodity price volatility increased over time? The answer is no: there is little evidence of trend since 1700. Have commodities always shown greater price volatility than manufactures? The answer is yes. Higher commodity price volatility is not the modern product of asymmetric industrial organizations - oligopolistic manufacturing versus competitive commodity markets - that only appeared with the industrial revolution. It was a fact of life deep into the 18th century. Does world market integration breed more or less commodity price volatility? The answer is less. Three centuries of history shows unambiguously that economic isolation caused by war or autarkic policy has been associated with much greater commodity price volatility, while world market integration associated with peace and pro-global policy has been associated with less commodity price volatility. Given specialization and comparative advantage, globalization has been good for growth in poor countries at least by diminishing price volatility. But comparative advantage has never been constant. Globalization increased poor country specialization in commodities when the world went open after the early 19th century; but it did not do so after the 1970s as the Third World shifted to labor-intensive manufactures. Whether price volatility or specialization dominates terms of trade and thus aggregate volatility in poor countries is thus conditional on the century.
\end{abstract}

David S. Jacks

Department of Economics

Simon Fraser University

8888 University Drive

Burnaby, BC V5A 1S6

CANADA

and NBER

dsjacks@gmail.com

Kevin H. O'Rourke

Department of Economics and IIIS

Trinity College

Dublin 2, IRELAND

and NBER

kevin.orourke@tcd.ie
Jeffrey G. Williamson

350 South Hamilton Street

Apartment 1002

Madison, WI 53703

and NBER

jwilliam@fas.harvard.edu 


\section{Commodity Price Volatility and Development}

Poor countries are more volatile than rich countries. This fact is not only a problem in itself, but it also impairs future growth prospects, especially in countries with imperfect capital markets. Miklós Koren and Silvana Tenreyro (2007) decompose the sources of this excess volatility in poor countries into various components, and find that roughly half can be explained by the fact that developing countries experience bigger and more frequent aggregate shocks than do rich countries. This paper is concerned with the other half of the story, that developing countries specialize in fewer and more volatile economic activities.

Poor countries have a more highly concentrated production structure, which leaves them more vulnerable to sectoral shocks, given that they do not diversify their risk across sectors as much as do rich countries (Koren and Tenreyro 2007). They also specialize in activities which are inherently more volatile. In addition, poor country industries face more elastic demand curves (and unskilled labor supply curves), while rich country industries face more inelastic demand curves (and skilled labor supply curves), so that supply shocks lead to more quantity adjustment in poor countries. Aart Kraay and Jaume Ventura (2007) provide one explanation for the latter phenomenon: unskilled-labor-abundant countries tend to specialize in unskilled-laborintensive sectors using traditional technologies. Finally, given that innovation in today's world economy largely takes place in rich skill-abundant countries, new technologies tend to be skillusing (Acemoglu 1998), and hence poorer countries end up specializing in industries which use traditional, low-productivity and slow-changing technologies.

Poor countries also face higher volatility since they specialize in agricultural and mineral production. Primary products, or export commodities as they are often called, experience far 
greater price volatility than do manufactures or services, although this is more often assumed than demonstrated in the literature. ${ }^{1}$ One exception to the "no evidence" rule is UNCTAD (2008: p. 38-40), which provides graphical evidence of higher price volatility for non-fuel commodities and petroleum than for manufactures between 1970 and 2008. Another is Ilse Mintz (1967), who, more than forty years ago, documented lower US export price volatility for finished manufactures than for semi-manufactures, crude materials or food between 1880 and 1963. It is this distinction between rich and poor countries that motivates the present paper. Less diversification and more specialization in more volatile activities yields more volatile terms of trade, a major source of the overall economic instability which poor countries face. Table 1 shows that this has indeed been the case since 1960. Compared with the manufactures-exporting industrial economics, the rest of the world had far higher terms of trade volatility, indeed more than three times higher in Latin America, South Asia and Africa.

Recent analysis of modern Third World economies informs us that price volatility of this sort is bad for long run growth. Observers regularly point to commodity price and terms of trade shocks as a key source of macroeconomic instability in commodity-specialized countries, but, until very recently, they paid far less attention to the long run growth implications of such instability. ${ }^{2}$ Economists stress the investment channel in looking for connections between commodity price volatility and growth. Indeed, the development literature offers abundant contemporary microeconomic evidence linking income volatility to lower investment in physical

\footnotetext{
${ }^{1}$ Here are two examples. Radetzki (2008: pp. 64-6) discusses the "well-known and off-repeated" observation that commodity prices are extremely volatile, and that "the prices of manufactures tend to be more stable". He provides evidence of volatile commodity prices, and discusses why these might be expected to be more volatile than manufactured prices. However, he does not provide or cite empirical evidence regarding the relative volatility of the two types of prices. Szirma (2005: p. 543), on the other hand, takes the view that "prices of primary exports turn out to be no more unstable than those of manufactured goods or capital goods", again without providing evidence.

${ }^{2}$ For important early exceptions, see Easterly et al. (1993), Deaton and Miller (1996), Mendoza (1997), Deaton (1999), Kose and Reizman (2001), and Bleaney and Greenway (2001). The more recent (booming) literature is reviewed below in the text.
} 
capital, human capital and even research and development. Households imperfectly protected from risk change their income-generating activities in the face of income volatility, diversifying towards low-risk alternatives with lower average returns, as well as to lower levels of investment (Roumasset 1976, 1979; Rosenweig and Wolpin 1993; Dercon 2004; Fafchamps 2003). Furthermore, severe cuts in health and education follow negative income shocks to poor households in the Third World — cuts that disproportionately affect children and hence long term human capital accumulation (Jensen 2000; Jacoby and Skoufias 1997; Frankenburg et al. 1999; Thomas et al. 2004).

Poor households find it difficult to smooth their expenditures in the face of shocks because they are rationed in (or even excluded from) credit and insurance markets, so they lower investment and take fewer risks with what remains. Poor, small family firms (also excluded from credit and insurance markets) find it difficult to smooth net returns on their assets, so they lower investment and take fewer risks with what remains. Perhaps most importantly, revenue sources geared to taxes on import and export trade ${ }^{3}$ will themselves be volatile. Thus, poor governments whose revenue sources are mainly customs duties (Coatsworth and Williamson 2004; Williamson 2006; Bates et al. 2007) and which also find it difficult to borrow at cheap rates locally and internationally, cannot, without serious difficulty, smooth public investment on infrastructure and education in the face of terms of trade shocks. ${ }^{4}$ Lower public investment ensues, and growth rates fall. In short, theory informs us that higher volatility in commodity

\footnotetext{
${ }^{3}$ To state the obvious, the first order effect is directly on export taxes given price volatility of export commodities, but the (bigger) second order indirect effect is on import customs revenues as import demand exhibits the same volatility due to the impact of export earnings on domestic income.

${ }^{4}$ While greater volatility increases the need for international borrowing to help smooth domestic consumption, Catão and Kapur (2004) have shown recently that volatility constrained the ability to borrow between 1970 and 2001. It seems likely that the same was true between 1870 and 1901, a century earlier, and even more so before 1870 when a global capital market was only just emerging (Obsfelt and Taylor 2004; Mauro et al. 2006).
} 
prices and the terms of trade should reduce investment and growth in the presence of risk aversion. In addition, the less-risky investment that does take place will also be low-return.

Modern evidence seems to be consistent with the theory. Using data from 92 developing and developed economies between 1962 and 1985, Garey and Valerie Ramey (1995) found government spending and macroeconomic volatility to be inversely related, and that countries with higher volatility had lower mean growth. This result has since been confirmed for a more recent cross-section of 91 countries (Fatás and Mihov 2006). Studies like these have repeatedly found that macroeconomic volatility diminishes long run growth (e.g. Acemoglu et al. 2003; Hnatkovska and Loayza 2005; Loayza et al. 2007), and we now know more about why it is especially acute in poor countries. In an impressive analysis of more than 60 countries between 1970 and 2003, Steven Poelhekke and Frederick van der Ploeg (2007) find strong support for the core-periphery asymmetry hypothesis regarding volatility, and with a large set of controls. Furthermore, while capricious policy and political violence can and did add to volatility in poor countries, extremely volatile commodity prices "are the main reason why natural resources export revenues are so volatile” (Poelhekke and van der Ploeg 2007: p. 3), and thus why those economies are themselves so volatile. While we have offered some reasons why poor countries face higher volatility and why that higher volatility costs them so much more in diminished growth rates, Philippe Aghion and his collaborators $(2005,2006)$ offer more: macroeconomic volatility driven either by nominal exchange rate or commodity price movements will depress growth in poor economies with weak financial institutions and rigid nominal wages, both of which characterized all poor economies in the past even more than today. ${ }^{5}$ Thus, "given the high volatility of primary commodity prices ... of many resource-rich countries, we expect resources-

\footnotetext{
${ }^{5}$ See also Aizenman and Marion (1999), Flug et al. (1999), Elbers et al. (2007), and Koren and Tenreyro (2007).
} 
rich countries with poorly developed financial systems to have poor growth performance” (Poelhekke and van der Ploeg 2007: p. 6).

Finally, recent work by economic historians has confirmed that price volatility was also bad for growth in poor (but not in rich) primary producing countries between 1870 and 1940 (Blattman et al. 2007; Williamson 2008).

\section{International Trade and Terms of Trade Volatility}

International trade might be thought to encourage terms of trade volatility, since it leads to specialization. If the specialization is in commodities rather than manufactures or services, then trade will increase terms of trade volatility even more. These arguments hold, keeping constant the price volatility of individual commodities. In this paper, however, we will look more closely at long run trends in the price volatility of individual goods, and ask whether this volatility has changed over time. Were commodity prices just as volatile two or three hundred years ago as they are today? Have they always been more volatile than the prices of manufactured goods? And, crucially, has this price volatility experience varied with how well local economies are integrated into a larger world economy? The latter point is particularly important, since if international trade lowers the price volatility of individual commodities, then it might on balance lead to a more stable price environment overall, even for countries with a comparative advantage in primary products.

Why might trade lower the volatility of individual commodity prices? The idea, of course, is that local shocks to supply and demand are stabilized when the local economy trades 
with the large world economy. Thus, when the world went global in the early $19^{\text {th }}$ century after the European wars, did commodity prices become less volatile as small local economies became integrated with large world markets? When the world went autarkic between the World Wars, did commodity prices become more volatile, for symmetric reasons? What about war and peace? Were commodity prices more volatile during the French Wars of the late $18^{\text {th }}$ and early $19^{\text {th }}$ century, and during World War I and World War II, than during the long $19^{\text {th }}$ century pax Britannica or the pro-global decades since 1970? What does history tell us about the commodity price volatility and world market integration connection?

This is hardly the first time that these questions have been raised, although this paper will be the first time, to our knowledge, that these questions have been confronted with extensive long run price evidence. Karl Gunnar Persson, scholar of medieval and early modern European grain markets, tells us how central these questions were to the $18^{\text {th }}$ century physiocrats, or what Persson calls les économistes. As far as les économistes were concerned, "the best and favoured remedy against price fluctuations was market integration, and its prerequisite was free trade in grain” (Persson 1999: p. 7). Furthermore, it appears that les économistes anticipated the modern development economist's conclusion that volatility is bad for growth by more than 300 years: "One of the accomplishments of [les économistes] was the claim that price volatility ... had disincentive effects on investment and effort in agriculture ... and that [it was] a prime cause for the distressed state of agriculture” (Persson 1999: p. 7). One of the earliest of les économistes, the Englishman Charles Davenant, asserted in 1699 that “a stable price would reign if [national grain] markets were permitted to trade since price differences would make traders move grain from surplus to deficit regions or nations” (Persson 1999: pp. 8-9, citing Davenant 1699: p. 82). So, were les économistes right? 


\section{Commodity Price Volatility since 1700: Data and Measurement}

Three questions motivate this paper. First, when the world went from anti-global (pre1820) to pro-global (1820-1913), and went again a century later from anti-global (1914-1949) to pro-global (1950-2009), did commodity price volatility fall? Second, has there been any secular trend in commodity price volatility since 1700 , or has it been a constant fact of economic life? Third, have primary product commodities always had more volatile prices than manufactured goods, or did this difference arise only with modern capitalism and the price stickiness associated with less competitive industrial organizations in manufacturing compared with the primary sector?

\section{Three Hundred Years of Price Data}

The most recent and comprehensive paper on modern commodity price behavior is by Poelhekke and van der Ploeg (2007). The price data used there are "monthly averages of freemarket price indices for all food, agricultural raw materials, minerals, ores \& metals, crude petroleum (average of Dubai/Brent/Texas equally weighted). Base year $2000=100$.” The source of these data is UNCTAD, Commodity Price Statistics (2007). We will use similar free market price statistics, except that they will be quoted in local city markets, so that they will reflect the impact of tariffs and embargoes. Our data are monthly price quotes for various items which are allocated, following UNCTAD classifications, to three groups: all food = AF, agricultural raw materials = ARM, and minerals, ores and metals = MOM. We add a fourth group for 
manufactures or final goods $=$ FG . These are further aggregated into all items $=$ ALL and all commodities $=$ COM .

Table 2 describes the data in greater detail. Nine series are monthly and listed in Panel 2A. The famous Philadelphia data base collected by Anne Bezanson and her collaborators (1935, 1936, 1951 and 1954) is in four parts, 1720-1775 (19 items), 1770-1790 (25 items), 1784-1861 (133 items), and 1852-1896 (100 items). The Dutch data collected by Nicolaas Posthumus (1946) and the Danish data collected by Astrid Friis and Kristof Glamann (1958) are both much shorter (1750-1800), and smaller (49 and 29 items). The data underlying the Gayer-RostowSchwartz (1953) British commodity price index for 1790-1850 contain 69 items. Our historical price data base is augmented with the monthly commodity price series published by the IMF (45 series) for 1980-2008 and UNCTAD (52 series) for 1960-2007. As we shall see below (Table 6), we also have quarterly data for United States exports 1880-1963.

In Panel 2B, two annual series are listed. The English series collected by Gregory Clark (2005) covers 1700-1869, and contains 36 items. The Sauerbeck (1886-1917) and Statist (1930) annual British price series cover 1850-1950, and contain 41 items. The annual series have, of course, lower frequency, and thus are not exactly comparable to the monthly series, but they do offer the advantage of more observations from the world's most important $19^{\text {th }}$ century market Great Britain - and, perhaps more importantly, coverage of the first half of the $20^{\text {th }}$ century. The AF category is represented by, among others: beef, butter, cheese, codfish, coffee, corn, flour, herring, molasses, oats, pepper, pork, rice, rye, salt, sugar, tea and wheat; the ARM category by: cotton, flax, hemp, indigo, logwood, leather, linseed oil, sperm oil, starch, staves, tallow and tobacco; the MOM category by: alum, ashes, brimstone, coal, copper, lead, nitrate, and saltpeter; and the FG category by: brandy, candles, cordage, duck cloth, gin, gunpowder, bar iron, pig iron, 
sheet iron, nails, shingles, shoes, shot, soap, steel, thread, tin plate, turpentine, wine, wool cloth, and yarn. Appendix I provides full details for the commodities and classifications employed below for the historical price data, while Appendix II repeats the exercise for the IMF and UNCTAD data.

\section{Commodity Price Volatility since 1700: Analysis}

\section{Have Commodity Prices Always Been More Volatile?}

Have commodities always exhibited greater volatility than manufactures? The answer is unambiguous: yes. Table 3 reports the price volatility of all items, primary product commodities (COM) and final manufactured goods (FG) for the two centuries between 1700 and 1896.

Volatility is calculated as the standard deviation of the price ratio, $\ln \left(\mathrm{P}_{\mathrm{t}} / \mathrm{P}_{\mathrm{t}-1}\right)$, that is, the standard deviation of the percentage changes in price over a given period. For instance, in the first row of Table 3, we calculate our metric for volatility over the entire set of $672\left(=56^{*} 12\right)$ monthly observations available for Philadelphia from 1720 to 1775 . In the case of annual prices, as in the seventh row of Table 3—-that for England from 1700 to 1819—we likewise gather all available observations on the logged price ratio (in this case, $\mathrm{N}=120$ ) and calculate the standard deviation. The volatility of COM and FG relative to all items is also reported in parentheses. In every case over these 200 years, the relative volatility indicator is less than 100 for FG. In some cases where the FG sample is very small, the difference between the volatility of the two commodity categories is small. This is particularly true of the data for 1720-1775 Philadelphia, where we have just three observations for the FG category (and they are all for spirits). Apart from that 
case, price volatility for manufactured goods ranged from 74 percent less (Denmark 1750-1800) to 9 percent less (Britain 1790-1819) than the average volatility for all goods. The unweighted average between 1700 and 1896 tells us that manufactured goods prices were 25 percent less volatile than all items, while commodity prices were 5 percent more volatile; alternatively, the price volatility for commodities was 40 percent higher than for manufactures. The figures for US export price volatility 1880-1963 (Table 6) are very similar: manufactured goods prices had 25 percent less volatility than all items, while commodity prices had 19 percent more; alternatively, the price volatility of commodities was 59 percent higher than that of manufactures.

While commodity prices have always been more volatile than manufactures, given what we know about the much greater terms of trade volatility in poor countries than in rich (Table 1; Williamson 2008), one might have expected an even bigger difference than the 40-59 percent average over the two and a half centuries before 1950. Recall, however, that the higher terms of trade volatility in primary product exporting countries has two parts: they specialize in commodities that are 40-59 percent more price volatile, and they have higher product concentration and thus lower diversification.

The results in Table 3 also offer little support for the hypothesis that commodity prices became more volatile than industrial prices because movements in the latter have been dampened by the rise of the modern industrial corporation, a view championed by Raúl Prebisch (1950) more than 50 years ago. ${ }^{6}$ If this were the case, then the gap between the volatility for the two categories should only have emerged some time in the late $19^{\text {th }}$ century. To be sure, the data for Philadelphia indicate that the difference between COM and FG was notably less pronounced before 1790 than afterwards, but, as has been suggested already, this may be a function of the

\footnotetext{
${ }^{6}$ See the excellent survey in Cuddington et al. (2007).
} 
small number of goods included in the data base for the earlier years. More to the point, the timing of this shift is too early to fit the Prebisch hypothesis. Moreover, there is little difference between the relative volatility of manufactured goods prices during the two sub-periods 17841861 and 1852-1896 (with the lower relative volatility of industrial prices actually being somewhat less in the latter period). As the next section will make clear, the latter comparison may be affected by the fact that both sub-periods included episodes of war as well as of peace, and so Table 3 also provides a comparison between 1873-84 and 1885-96. These results do show a decline in the relative volatility of manufactured goods over the course of the late $19^{\text {th }}$ century, and the timing here is consistent with the rise of the modern corporation. Overall, however, the main message emerging from these data is that commodity prices have been more volatile than manufactured goods prices over the past three centuries, not just today, or just since the 1950s.

\section{Have Commodity Prices Become More Volatile Over Time?}

Has the price volatility of commodities risen over time, so that modern commodity exporters suffer more economic volatility than they did 300 years ago? The answer here is again unambiguous, but this time, it is no. This finding requires two qualifications. First, since it is unwise to make comparisons between market locations -- the samples being different between them -- we can only explore this question by looking within market locations. Table 3 offers no support for the rising volatility hypothesis within the Philadelphia 1720-1896 series, within the English 1700-1869 series, or within the British 1790-1850 series. Table 4 offers more evidence, since the Sauerbeck-Statist data have been added. Comparing peacetime with peacetime (see the next section), the Clark data show higher volatility during 1820-60 than during 1700-1775;

however, the Sauerbeck-Statist data show no evidence of a secular peacetime rise from 1850 
onwards, and the same is true of US export prices from 1880 to 1963 (Table 6). We will have more to say about the war and interwar evidence in a moment.

The second qualification to this finding comes from the post-1960 data in Table 5. Neither the IMF nor the UNCTAD data show a clear rising trend in commodity price volatility from the 1980s onwards. However, the UNCTAD data do show that price volatility was considerably lower in the 1960s than subsequently. In order to conclude unambiguously that this constituted an upward trend following the Second World War, rather than that the 1960s were simply a period of unusually low price volatility, we would need data documenting the late 1940s and 1950s compared to what followed. Mintz (1967: Table A-3, pp. 300-7) offers the only evidence which we have been able to uncover which can be used to confront the issue of unusually low price volatility during this period, and her quarterly data are used to calculate the price volatility reported in Table 6. US export prices between 1950 and 1963 exhibited about one third the volatility that they did between 1880 and 1950. Prices of US food and finished manufactured exports exhibited pretty much the same pattern, as did prices of US semimanufactured and crude material exports (although neither can be documented over the full period). We also know that the 1960s were a period of macroeconomic and exchange rate stability, relative to what came subsequently, and this might perhaps explain the contrast between what is called the Bretton Woods period and what followed. Indeed, John Cuddington and Hong Liang (2003) show that over the period 1880-1996, there was greater volatility in the relative price of commodities to manufactured goods during periods of floating exchange rates than during periods of fixed exchange rates. The evidence in Tables 5 and 6 shows that what was true of this relative price was also true of both the numerator and the denominator by themselves. 
This result mirrors the findings reported by Paul Cashin and John McDermott (2002) that there was an increase in the volatility of the Economist's industrial commodity price index after $1971 .^{7}$

\section{Are Commodity Prices More Volatile During War and Anti-Global Autarkic Regimes?}

If local shocks to supply and demand matter less for domestic prices when the local economy trades with the large world economy, commodity prices should be less volatile when the world is more pro-global. Thus, did commodity prices become less volatile when the world went global in the $19^{\text {th }}$ century after the European wars, and did commodity prices become more volatile when the world went autarkic between the World Wars? Table 4 strongly confirms these predictions.

First, consider the wars of 1776-1815, which severely disrupted commodity markets worldwide (O’Rourke 2006), especially in the Atlantic economy from whence our data are drawn. The Clark and Gayer-Rostow-Schwartz series for England, the Friis-Glamann series for Denmark, the Posthumus series for the Netherlands and the Bezanson series for Philadelphia all show higher price volatility during war (1776-1819) than in either the previous or the subsequent period. In all cases bar one (the Gayer-Rostow-Schwartz series) the differences between subperiods are statistically significant. ${ }^{8}$ It seems that the French and American Revolutionary Wars, the Napoleonic Wars, and the War of 1812, did not just lead to terms of trade deteriorations across the Atlantic economy, and hence to sizeable welfare losses (Irwin 2005; O’Rourke 2007). They also increased price volatility. If this had the same negative impact on investment as it does in developing countries today, then this would have reduced growth over and above the negative

\footnotetext{
${ }^{7}$ The Economists's industrial commodities price index is heavily weighted towards commodities, although it also includes some basic manufactured goods.

${ }^{8}$ The p-value of an F test on the equality of variances in the latter case is equal to 0.1467 .
} 
effects which wartime investment crowding out would have implied on its own (Williamson 1984).

These data can also be used to explore the impact of the American Civil War on commodity price volatility. Again, we know from the literature on the Cotton Famine that the Civil War had an impact on the terms of trade in cotton-importing and cotton-exporting parts of the world, but did it increase commodity price volatility? In Britain, which was not a belligerent, the answer appears to be no, according to the Sauerbeck-Statist evidence. Britain's terms of trade may have deteriorated as a result of greater US cotton scarcity, but it was still trading freely with the rest of the world, and there was no increase in price volatility there. The United States underwent a quite different experience: the Bezanson price data show a very large (and statistically significant) increase in volatility during 1861-72 as compared to what came before or after, a result consistent with the fact that much of the American economy was cut off from world markets during the conflict. The biggest anti-global world regime in our period, however, was 1914-1950, which saw two World Wars and an intervening period characterized by Depression and autarky. During the four decades 1914-1950, price volatility was twice as great as it was in the peacetime decades that preceded them, at least according to the Sauerbeck-Statist evidence. The Mintz quarterly price data whose volatility is summarized in Table 6 certainly confirms this for the autarkic interwar decades: the average volatility figure for all commodities 1920-1950 is 0.039, or half again higher than the average for 1880-1914 and 1950-1963 (0.026). This finding mirrors that of Frederick Mills (1926: p. 46) who almost a century ago found that two thirds of the commodities whose prices he was investigating displayed greater price volatility during 1922-25 than during 1906-13. His conclusion was that "The influence of the war-time disturbances upon individual prices has persisted, apparently, and, in so far as the four 
years from 1922 to 1925 may be used as a criterion, has left us with more variable prices than we had during the years immediately preceding the war.”

As previously mentioned, Cuddington and Liang (2003) have explored the volatility of the price of commodities relative to the price of manufactured goods. Using the Grilli-Yang data (1988), they find that volatility was lower in 1946-71 than in any subperiod between 1914 and 1938 (although as already mentioned, volatility then increased substantially after 1972). ${ }^{9}$ Cashin and McDermott (2002) find that the Economist's annual industrial commodity price index 18621999 documents a volatility increase in the early 1900s (with the First World War appearing to be an important breakpoint), and again after 1971. Unfortunately they do not present the data in such as way as to be able to see clearly if the Bretton Woods period saw lower volatility than 1914-50. However, and as we have seen, the Mintz data in Table 6 does confirm lower price volatility during the Bretton Woods era.

\section{Concluding Remarks}

This paper is motivated by the common observation that poor countries are more volatile than rich countries, and that this volatility impedes their growth performance. Furthermore, it appears that roughly half of this excess volatility can be explained by the fact that poor countries experience bigger and more frequent aggregate shocks than do rich countries. Finally, it also appears that commodity price volatility is a key source of those shocks.

\footnotetext{
${ }^{9}$ On the other hand, using the Boughton (1991) data, they find that although 1946-71 volatility was lower than 1927-38 volatility, it was higher than volatility between 1914 and 1926, and that volatility after 1972 was higher still.
} 
Here we explore price data for primary products (commodities) and manufactures over the past three centuries to answer three questions: First, has commodity price volatility increased over time? The answer is unambiguously no. Indeed, there is little evidence of trend since 1700. Second, have commodities always shown greater price volatility than manufactures? The answer is unambiguously yes. Higher commodity price volatility is not some Prebisch-like modern product of asymmetric industrial organization - monopolistic and oligopolistic manufacturing versus competitive commodity markets - that only appeared with the industrial revolution. Instead, it was a fact of life deep into the $18^{\text {th }}$ century. Third, do globalization and world market integration breed more or less commodity price volatility? The answer is less. One can imagine a tug of war between two off-setting forces: on the one hand, the impact of supply shocks in commodity-exporting countries is diminished by the integration of small local markets with large world markets; but on the other hand, by their integration into world markets commodityexporting countries expose themselves to world demand instability generated by cyclical booms and busts in the industrial countries. Three centuries of history shows unambiguously that the former dominates the latter: economic isolation caused by war or autarkic policy has been associated with much greater commodity price volatility, while world market integration associated with peace and pro-global policy has been associated with less commodity price volatility. Given specialization and comparative advantage, globalization has been good for growth in poor countries to the extent that it has reduced commodity price volatility. But, of course, specialization is not given, but rather endogenous to policy regimes. Thus, globalization also increased poor country specialization in commodities when the world went open after the early $19^{\text {th }}$ century; but it did not do so after the 1970s as the Third World shifted to laborintensive manufactures (Martin 2007). Whether the price volatility or the specialization effect 
dominates may thus be conditional on the century. In any case, since this issue deals with countries, while the present paper deals with individual commodities, the answer must be left to future research. ${ }^{10}$

${ }^{10}$ Some answers are already beginning to emerge in Blattman et al. (2007) and Williamson (ongoing). 


\section{Appendix 1: Commodity Classifications for Historical Price Data}

\section{Philadelphia, 1720-1775}

AF: Beef; Bread, middling; Corn; Flour; Molasses; Pork; Rice; Salt, coarse; Salt, fine; Sugar, Muscavado; Wheat.

ARM: Pitch; Staves, hogshead; Staves, pipe; Tar.

FG: Rum, West Indian; Turpentine; Wine, Madeira.

\section{Philadelphia, 1770-1795}

AF: Beef; Bread, ship; Chocolate; Coffee; Flour, common; Flour, middling; Flour, superior; Molasses; Pepper; Pork; Rice; Sugar, loaf; Sugar, Muscavado; Tea, Bohea; Wheat.

ARM: Cotton; Indigo; Leather, sole; Tar; Tobacco

FG: Iron, bar; Rum, West Indian; Turpentine; Wine

\section{Philadelphia, 1786-1861}

AF: Almonds; Beef; Beef, mess; Bread; Bread, pilot; Butter; Cheese; Chocolate; Clove; Cocoa; Codfish, dried; Coffee; Corn; Corn meal; Currents; Flaxseed; Flour, superfine; Ginseng; Hams; Herring; Honey; Lard; Lemons; Mace; Mackerel; Mackerel 1; Mackerel 3; Molasses; Nutmeg; Oats; Peas; Pepper; Pimento; Pork; Pork, Burlington \& mess; Pork, prime; Raisins; Rice; Rye; Rye meal; Salt, coarse; Salt, fine; Sugar, Havana brown; Sugar, Havana white; Sugar, loaf \& lump; Tea; Tea, Hyson; Tea, Souchong; Wheat.

ARM: Beaver; Beeswax, yellow; Cotton; Deer skins; Feathers; Flax; Fustic; Hemp, Russian; Hides; Indigo; Leather; Logwood; Logwood, Campeachy; Muskrat; Oil, linseed; Oil, sweet; Oil, sperm; Oil, whale; Pine, heart \& panel; Pine, sap; Pitch; Rosin; Spirits of turpentine; Starch; Staves, barrel; Staves, hogshead; Staves, pipe; Tallow; Tar; Tobacco, James River; Tobacco, Kentucky

MOM: Alum; Ashes, pearl; Ashes, pot; Brimstone, rolls; Coal, Virginia; Copper, sheathing; Lead; Lead, red dry; Lead, white dry; Lead, white in oil; Saltpeter, refined; Verdigris.

FG: Brandy, French; Candles, sperm; Candles, tallow; Candles, tallow tipped; Candles, tallow mold; Copperas; Cordage, foreign; Duck, bear ravens; Gin, Holland; Ginger, ground; Gunpowder; Iron, bar domestic; Iron, bar foreign; Iron, bar Swedish; Iron, pig; Iron, sheet; Nails; Plaster of Paris; Rum, New England; Sheeting, Russian brown; Shingles; Shot; Soap, Castile; Soap, white; Soap, yellow; Spanish Brown, dry; Spanish Brown, in oil; Steel, American; Steel, English; Steel, German, Steel, T Crowley; Tin, plate; Turpentine; Wine, Lisbon; Wine, Madeira; Wine, Malaga; Wine, port; Wine, sherry; Wine, Tenerife cargo.

\section{Philadelphia, 1852-1896}

AF: Almonds; Beef, dried; Beef, hams; Beef, mess; Butter; Cheese; Cloves; Cocoa; Codfish, dried; Coffee; Corn; Corn meal; Currants; Flour, Superfine; Ginger, race; Hams; Herring; Lard; Lemons; Mace; Mackerel; Molasses; Nutmeg; Oats; Pepper; Pimento; Pork, Burlington \& mess; Raisins; Rice; Rye; Salt, coarse; Salt, fine; Sugar, loaf \& lump; Tea; Tea, Hyson; Tea, Souchong; Wheat, red Pennsylvania. 
ARM: Beaver; Beeswax, yellow; Cotton, LA \& MS; Deer skins; Feathers; Fustic; Hemp, Russian; Hides; Indigo; Leather; Logwood; Logwood, Campeachy; Muskrat; Oil, linseed; Oil, sperm; Oil, whale; Pine, heart \& panel; Pitch; Rosin; Starch; Staves, barrel; Staves, hogshead; Staves, pipe; Tallow; Tar.

MOM: Alum; Ashes, pearl; Ashes, pot; Brimstone, rolls; Coal, bituminous; Copper, sheathing; Lead, bar; Lead, red dry; Lead, white dry; Lead, white in oil; Saltpeter, refined; Verdigris

FG: Candles, adamantine; Candles, sperm; Copperas; Cordage, foreign; Gin, Holland; Gunpowder; Iron, bar domestic; Iron, pig; Iron, sheet; Nails; Plaster of Paris; Rum, New England; Sheeting, Russian brown; Shingles; Shot; Soap, Castile; Spirits of turpentine; Steel, American; Steel, English; Steel, German; Tin, plate; Wine, Madeira; Wine, Malaga; Wine, port; Wine, sherry.

\section{Britain, 1790-1850}

AF: Beef; Butter; Cinnamon; Cocoa; Coffee; Ginger; Liqourice; Oats; Pepper; Pork; Seeds; Sugar; Tea; Wheat.

ARM: Annato; Balsam; Barilla; Beeswax; Bristles; Camphor; Cochineal; Cotton; Flax; Fustic; Hemp; Hides; Indigo; Isinglass; Leather butts; Linseed; Linseed oil; Logwood; Madder root; Mahogany; Olive oil; Quinine; Rape oil; Raw silk; Starch; Staves; Sumac; Tallow; Tar; Timber; Tobacco; Whale fins; Whale oil; Wool.

MOM: Alum; Ashes; Brimstone; Copper; Lead; Quicksilver; Sal Ammoniac; Saltpetre; Vitriol.

FG: Brandy; Iron; Iron, bars; Iron, pig; Rum; Silk, thrown; Soap, mottled; Soap, yellow; Tin, black; Turpentine; Wine.

\section{Denmark, 1750-1800}

AF: Bacon; Barley; Barley groats; Buckwheat groats; Butter, Funen; Cheese, Holstein; Cod, Icelandic salted; Cod, split; Herring, Danish autumn; Malt; Oatmeal; Oats; Peas; Rye, Danish; Salt, Copenhagen; Salt, Spanish; Stockfish, Icelandic; Wheat, Danish.

ARM: Beechwood, Holstein; Flax; Hemp; Hops, Brunswick; Tallow; Tar; Train oil.

FG: Brandy, French; Iron, Norwegian; Soap, soft; Wine, French.

\section{The Netherlands, 1750-1800}

AF: Barley, Frisian winter; Beans, horse; Buckwheat, Brabant; Candy, white; Cinnamon; Cloves; Cocoa, Caracas; Nutmeg; Oats, forage; Rye, Konigsberg; Salt, white; Stockfish, split; Sugar, loaf; Sugar, refined; Sugar, Surinam; Tea, Buoy; Treacle; Wheat, Polish.

ARM: Camphor, refined; Codliver oil; Coleseed, Flemish; Cotton, Smyrna; Hides, native, salted; Indigo, Java; Linseed, Riga, crushed; Linseed oil; Madder, common; Opium; Rape oil; Sole leather; Starch; Tobacco; Train, oil; Whale bones; Wool, Andalusian; Wool, Segovia, washed.

MOM: Alum, English; Borax, refined; Lead, white; Potash, Dantzig; Sulphur, refined.

FG: Copperas, English; Gunpowder; Iron, single, white; Sail yarn; Soap, Marseilles; Thread, card, Maastricht; Turpentine, Venetian; Wine, Bordeaux. 


\section{England, 1700-1869}

AF: Barley; Beans; Beef; Beer, strong; Butter; Cheese; Eggs; Flour; Milk; Mutton; Oats; Peas;

Pork; Raisins; Rice; Salt; Sugar; Wheat; Wheat flour.

ARM: Firewood; Hay; Hops; Lamp oil; Suet; Wood; Wool.

MOM: Coal; Coal, London; Coal, rest of England.

FG: Candles, tallow; Cloth, wool; Clothing; Iron manufactureds; Paper, foolscap; Shoes; Soap.

\section{Britain, 1850-1950}

AF: Bacon; Barley; Beef, middling; Beef, prime; Butter; Coffee, Ceylon; Coffee, Rio; Flour; Maize; Mutton, middling; Mutton, prime; Oats; Pork; Potatoes; Rice; Sugar, Java; Tea; Wheat, English.

ARM: Cotton; Cotton, Dollegargh; Flax, Russian; Hemp, Manila; Hemp, Russian; Hides, Argentine; Indigo; Jute; Leather; Linseed oil; Olive oil; Palm oil; Seeds; Silk; Timber, hewn; Wool, Adelaide; Wool, English; Wool, Merino.

MOM: Coals, Export; Coals, Wallsend; Copper, Chile; Lead; Nitrate. 


\section{Appendix 2: Commodity Classifications for Modern Price Data}

\section{IMF, 1980-2008}

AF: Bananas, Central American and Ecuador; Barley, Canadian no.1 western; Beef, Australian and New Zealand lean fores; Cocoa beans; Coffee, other mild arabicas; Coffee, robusta; Fish, farm bred Norwegian salmon; Groundnuts; Lamb, frozen carcass Smithfield London; Maize, U.S. No.2 yellow; Olive oil, extra virgin; Oranges; Palm oil; Poultry, whole chicken; Rapeseed oil, Crude; Rice, milled white; Shrimp, frozen shell-on headless; Soybean meal; Soybean oil, exchange approved grades; Soybeans, United States No. 2 yellow and par; Sugar, European import price; Sugar, Free Market; Sugar, U.S. import price; Sunflower oil; Swine, hogs; Tea, Mombasa; Wheat, No.1 hard red winter.

ARM: Cotton, middling; Fishmeal, Peru fish meal/pellets; Hides, heavy native steers; Logs, hard, best quality Malaysian meranti; Logs, soft, Douglas fir; Rubber, no.1 rubber smoked sheet; Sawnwood, hard, dark red meranti; Sawnwood, soft, Douglas fir; Wool, coarse; Wool, fine.

MOM: Coal, Australian thermal; Copper, grade A cathode; Iron ore, fine; Lead; Nickel, melting grade; Tin, standard grade; Uranium, u3o8; Zinc, high grade.

\section{UNCTAD, 1960-2007}

AF: Bananas, Central America and Ecuador; Beef, Australia \& New Zealand, frozen boneless; Cocoa beans; Coconut oil, Philippines; Coffee, Brazilian and other natural arabicas; Coffee, Colombian mild arabicas; Coffee, other mild arabicas; Coffee, robustas; Copra, Philippines/Indonesia; Cottonseed oil, United States; Fish meal; Groundnut oil; Palm kernel oil, Malaysia; Palm oil, mainly Indonesian; Pepper, white Sarawak/Muntok; Rice, Thailand, white milled; Soybean meal; Soybean oil; Soybeans, United States, No. 2 yellow; Sugar, in bulk; Sunflower oil; Wheat, United States, No. 2 hard red winter.

ARM: Cattle hides, United States, Chicago packer's heavy native steers; Cotton, Egypt, Giza 88, good; Cotton, Pakistan Sind/Punjab, SG Afzal; Cotton, United States, Memphis/Eastern, Middling; Cotton, United States, Memphis/Orleans/Texas, Middling; Jute, Bangladesh, BWD; Linseed oil; Rubber, in bales, No. 1 RSS; Sisal, Tanzania/Kenya, No. 2 \& 3 long; Sisal, Tanzania/Kenya, No. 3 \& UG; Tobacco, unmanufactured.

MOM: Aluminum, high grade; Copper, grade A, electrolytic wire bars/cathodes; Copper, wire bars; Iron ore, Brazilian; Lead; Manganese ore; Nickel cathodes; Phosphate rock, Khouribga; Tin; Tungsten ore; Zinc, Prime Western; Zinc, special high grade. 


\section{References}

Acemoglu, D. (1998), "Why Do New Technologies Complement Skills? Directed Technical Change and Wage Inequality,” Quarterly Journal of Economics 113 (November): 105589.

Acemoglu, D., S. Johnson, J. A. Robinson, and Y. Thaicharoen (2003), “Institutional Causes, Macroeconomic Symptoms: Volatility, Crises, and Growth,” Journal of Monetary Economics 50(1): 49-122.

Aghion, P., G.-M. Angeletos, A. Banerjee, and K. Manova (2005), “Volatility and Growth: Credit Constraints and Productivity-Enhancing Investments,” NBER Working Paper 11349, National Bureau of Economic Research, Cambridge, Mass.

Aghion, P., P. Bacchetta, R. Rancière, and K. Rogoff (2006), “Exchange Rate Volatility and Productivity Growth: the Role of Financial Development," CEPR Discussion Paper No. 5629, Centre for Economic Policy Research, London.

Aizenman, J. and N. Marion (1999), “Volatility and Investment: Interpreting Evidence from Developing Countries,” Economica 66(262): 157-79.

Bates, R., J. H. Coatsworth, and J. G. Williamson (2007), “Lost Decades: Lessons from Post-Independence Latin America for Today’s Africa,” Journal of Economic History 67 (December): 917-43.

Bezanson, A. (1951), Prices and Inflation during the American Revolution: Pennsylvania, 1770-1790 (Philadelphia: University of Pennsylvania Press).

Bezanson, A., R. D. Gray, and M. Hussey (1935), Prices in Colonial Pennsylvania (Philadelphia: University of Pennsylvania Press).

Bezanson, A., R. D. Gray, and M. Hussey (1936), Wholesale Prices in Philadelphia 1784-1861 (Philadelphia: University of Pennsylvania Press).

Bezanson, A., M. C. Denison, M. Hussey, and E. Kemp (1954), Wholesale Prices in Philadelphia 1852-1896 (Philadelphia: University of Pennsylvania Press). 
Blattman, C., J. Hwang, and J. G. Williamson (2007), "The Impact of the Terms of Trade on Economic Development in the Periphery, 1870-1939: Volatility and Secular Change,” Journal of Development Economics 82 (January): 156-79.

Bleaney, M. and D. Greenaway (2001), "The Impact of Terms of Trade and Real Exchange Rate Volatility on Investment and Growth in Sub-Saharan Africa," Journal of Development Economics 65(2): 491-500.

Boughton, J. M. (1991), “Commodity and Manufactures Prices in the Long Run,” IMF Working Paper WP/91/47, International Monetary Fund, Washington, D.C.

Cashin, P. and C. J. McDermott (2002), “The Long-Run Behavior of Commodity Prices: Small Trends and Big Variability,” IMF Staff Papers 49(2): 175-99.

Catão, L. and S. Kapur (2004), "Missing Link: Volatility and the Debt Intolerance Paradox.” International Monetary Fund, Washington, D.C., unpublished (January).

Clark, G. (2005), “The Condition of the Working Class in England, 1209-2004,” Journal of Political Economy 113(6): 1307-40.

Cuddington, J. T. and H. Liang (2003), “Commodity Price Volatility across Exchange Rate Regimes," mimeo, Georgetown University and IMF (March).

Cuddington, J. T., R. Ludema, and S. A. Jayasuriya (2007), “Prebisch-Singer Redux,” in D. Lederman and W. F. Maloney (eds.), Natural Resources: Neither Curse nor Destiny (Stanford: Stanford University Press).

Davenant, C. (1699), An Essay upon the Probable Methods of Making People Gainers in the Balance of Trade (London: James Knapton).

Deaton, A. S. (1999), “Commodity Prices and Growth in Africa," Journal of Economic Perspectives 13(3): 23-40.

Deaton, A. S. and R. I. Miller (1996), "International Commodity Prices, Macroeconomic Performance and Politics in Sub-Saharan Africa," Journal of African Economics 5(3): 99191, Supplement.

Dercon, S. (2004), Insurance Against Poverty (Oxford: Oxford University Press). 
Easterly, W., M. Kremer, L. Pritchett, and L. H. Summers (1993), “Good Policy or Good Luck? Country Growth Performance and Temporary Shocks,” Journal of Monetary Economics 32(3): 459-83.

Elbers, C., J. W. Gunning, and B. Kinsey (2007), “Growth and Risk: Methodology and Micro Evidence,” The World Bank Economic Review 21(1): 1-20.

Fafchamps, M. (2003), Rural Poverty, Risk and Development (Cheltenham: Edward Elgar).

Fatás, A. and I. Mivhov (2006), "Policy Volatility, Institutions and Economic Growth,” INSEAD, Singapore and Fontainebleau, France, unpublished.

Flug, K., A. Spilimbergo, and A. Wachtenheim (1999), "Investment in education: Do economic volatility and credit constraints matter?” Journal of Development Economics 55(2): 465-81.

Frankenberg, E., K. Beegle, B. Sikoki, and D. Thomas (1999), “Health, Family Planning and Well-being in Indonesia during an Economic Crisis: Early results from the Indonesian Family Life Survey,” RAND Labor and Population Program Working Paper Series 9906, Rand Corporation, Santa Monica, CA.

Friis, A. and K. Glamann (1958), A History of Prices and Wages in Denmark, 1660-1800 (London: Longmans Green).

Gayer, A. D., W. W. Rostow, and A. J. Schwartz (1953), Microfilmed supplement underlying The Growth and Fluctuation of the British Economy, 1790-1850 (Oxford: Clarendon Press).

Grilli, E. and M. C. Yang (1988), "Primary Commodity Prices, Manufactured Goods Prices, and the Terms of Trade of Developing Countries: What the Long Run Shows,” World Bank Economic Review 2(1): 1-47.

Hnatkovska, V. and N. Loayza (2005), "Volatility and Growth,” in J. Aizenman and B. Pinto (eds.), Managing Economic Volatility and Crises: A Practitioner's Guide (Cambridge: Cambridge University Press).

International Monetary Fund (2008), Primary Commodity Prices Database.

Irwin, D. A. (2005), “The Welfare Cost of Autarky: Evidence from the Jeffersonian Trade Embargo, 1807-09,” Review of International Economics 13(4): 631-45. 
Jacoby, H. G. and E. Skoufias (1997), "Risk, Financial Markets, and Human Capital in a Developing Country,” Review of Economic Studies 64 (July): 311-35.

Jensen, R. (2000), “Agricultural Volatility and Investments in Children,” American Economic Review 90 (May): 399-404.

Koren, M. and S. Tenreyro (2007), “Volatility and Development,” Quarterly Journal of Economics 122(1): 243-87.

Kose, M. A. and R. Reizman (2001), “Trade Shocks and Macroeconomic Fluctuations in Africa,” Journal of Development Economics 65(1): 55-80.

Kraay, A. and J. Ventura (2007), "Comparative Advantage and the Cross-Section of Business Cycles,” Journal of the European Economic Association 5(6): 1300-1333.

Loayza, N. V., R. Rancière, L. Servén, and J. Ventura (2007), “Macroeconomic Volatility and Welfare in Developing Countries: An Introduction,” World Bank Economic Review 21(3): 343-57.

Martin, W. (2007), “Outgrowing Resource Dependence: Theory and Developments,” in D. Lederman and W. F. Maloney (eds.), Natural Resources: Neither Curse nor Destiny (Stanford: Stanford University Press).

Mauro, P., N. Sussman, and Y. Yafeh (2006), Emerging Markets, Sovereign Debt, and International Financial Integration: 1870-1913 and Today (Oxford: Oxford University Press).

Mendoza, E. (1997), “Terms of Trade Uncertainty and Economic Growth,” Journal of Development Economics 54(2): 323-56.

Mills, F. C. (1926), The Behavior of Prices (New York: National Bureau of Economic Research).

Mintz, I. (1967), Cyclical Fluctuations in the Exports of the United States Since 1879 (New York: National Bureau of Economic Research).

Obstfeld, M. and A. M. Taylor (2004), Global Capital Markets: Integration, Crisis, and Growth (Cambridge; Cambridge University Press).

O’Rourke, K. H. (2006), “The worldwide economic impact of the French Revolutionary and Napoleonic Wars, 1793-1815,” Journal of Global History 1(1): 123-49. 
O’Rourke, K. H. (2007), “War and welfare: Britain, France and the United States 180714,” Oxford Economic Papers Supplementary Issue 59: i8-i30.

Persson, K. G. (1999), Grain Markets in Europe, 1500-1900 (Cambridge: Cambridge University Press).

Poelhekke, S. and F. van der Ploeg (2007), "Volatility, Financial Development and the Natural Resource Curse,” CEPR Discussion Paper 6513, Centre for Economic Policy Research, London (October).

Posthumus, N. W. (1946), Inquiry into the History of Prices in Holland (Leiden: Brill).

Prebisch, R. (1950), “The Economic Development of Latin America and Its Principal Problems.” Reprinted in the Economic Bulletin for Latin America 7(1): 1-22.

Radetzki, M. (2008), A Handbook of Primary Commodities in the Global Economy (Cambridge: Cambridge University Press).

Ramey, G. and V. A. Ramey (1995), “Cross-country Evidence on the Link Between Volatility and Growth,” American Economic Review 85(5): 1138-51.

Roumasset, J. A. (1976), Rice and Risk: Decision-Making among Low-Income Farmers (Amsterdam: North-Holland).

Roumasset, J. A., J-M. Boussard, and I. Singh (eds.) (1979), Risk, Uncertainty and Agricultural Development (New York: Agricultural Development Council).

Rosenzweig, M. R. and K. I. Wolpin (1993), “Credit Market Constraints, Consumption Smoothing, and the Accumulation of Durable Production Assets in Low Income Countries: Investments in Bullocks in India,” Journal of Political Economy 101(2): 22344.

Sauerbeck, A. (1886), "Prices of Commodities and the Precious Metals,” Journal of the Statistical Society of London 49(3): 581-648.

Sauerbeck, A. (1893), "Prices of Commodities During the Last Seven Years," Journal of the Royal Statistical Society 56(2): 215-54.

Sauerbeck, A. (1908), “Prices of Commodities in 1908,” Journal of the Royal Statistical Society 72(1): 68-80.

Sauerbeck, A. (1917), “Wholesale Prices of Commodities in 1916,” Journal of the Royal 
Statistical Society 80(2): 289-309.

Szirmai, A. (2005), The Dynamics of Socio-Economic Development: An Introduction (Cambridge: Cambridge University Press).

The Statist (1930), “Wholesale Prices of Commodities in 1929,” Journal of the Royal Statistical Society 93(2): 271-87.

Thomas, D., K. Beegle, E. Frankenberg, B. Sikoki, J. Strauss, and G. Teruel (2004), “Education in a Crisis,” Journal of Development Economics 74 (June): 53-85.

UNCTAD (2007), Commodity Price Statistics (New York: UN Conference on Trade and Development).

UNCTAD (2008), Trade and Development Report, 2008 (New York: UN Conference on Trade and Development).

Williamson, J. G. (1984), “Why Was British Growth So Slow During the Industrial Revolution?” Journal of Economic History 44 (September): 687-712.

Williamson, J. G. (2006), “Explaining World Tariffs 1870-1938: Stolper-Samuelson, Strategic Tariffs and State Revenues,” in R. Findlay, R. Henriksson, H. Lindgren, and M. Lundahl (eds.), Eli F. Heckscher, International Trade, and Economic History (Cambridge, Mass.: MIT Press, 2006).

Williamson, J. G. (2008), “Globalization and the Great Divergence: Terms of Trade Booms and Volatility in the Poor Periphery 1782-1913," European Review of Economic History 12 (December): 355-91.

Williamson, J. G. (ongoing), Trade and Poverty: When the Third World Fell Behind. 
Table 1 Comparative Terms of Trade Volatility by Region 1960-2000

\begin{tabular}{lcccccc}
\hline Decade & $\begin{array}{c}\text { Industrialized East Asia and } \\
\text { Economies }\end{array}$ & $\begin{array}{c}\text { Latin } \\
\text { the Pacific }\end{array}$ & $\begin{array}{c}\text { Middle East } \\
\text { America and }\end{array}$ & South Asia & $\begin{array}{c}\text { Sub-Saharan } \\
\text { africa }\end{array}$ \\
\hline $1960 \mathrm{~s}$ & 1.8 & 5.2 & 7.2 & 4.8 & 12.8 & 7.2 \\
$1970 \mathrm{~s}$ & 5.2 & 8.2 & 13 & 11.5 & 18 & 18.2 \\
$1980 \mathrm{~s}$ & 3.5 & 6.1 & 11 & 9 & 10.2 & 12.2 \\
$1990 \mathrm{~s}$ & 2.1 & 1.9 & 8.1 & 7.8 & 7.8 & 10.8 \\
\hline Average & $3.2(100)$ & $5.4(169)$ & $9.8(306)$ & $8.3(259)$ & $12.2(381)$ & $12.1(378)$ \\
\hline
\end{tabular}

Notes: These figures are taken from Loayza et al. (2007: Figure 3, p. 346). Terms of trade volatility is calculated as the standard deviation of the logarithmic change in terms of trade over each of the four decades 1960-2000. 
Table 2 Commodity Price Data Sources 1700-1950

\begin{tabular}{|c|c|c|c|}
\hline Market and Commodity & Source & Time Period & $\begin{array}{l}\text { Number of } \\
\text { Commodities }\end{array}$ \\
\hline & Panel 2A: Monthly Data & & \\
\hline Philadelphia & Bezanson et al. (1936) & $1720-1775$ & 19 \\
\hline $\mathrm{AF}$ & & & 11 \\
\hline ARM & & & 5 \\
\hline MOM & & & 0 \\
\hline FG & & & 3 \\
\hline Philadelphia & Bezanson et al. (1936) & $1770-1790$ & 25 \\
\hline$\overline{\mathrm{AF}}$ & & & 16 \\
\hline ARM & & & 5 \\
\hline MOM & & & 0 \\
\hline FG & & & 4 \\
\hline Philadelphia & Bezanson et al. (1936) & 1784-1861 & 133 \\
\hline $\mathrm{AF}$ & & & 51 \\
\hline ARM & & & 31 \\
\hline MOM & & & 12 \\
\hline FG & & & 39 \\
\hline Philadelphia & Bezanson et al. (1954) & 1852-1896 & 100 \\
\hline AF & & & 37 \\
\hline ARM & & & 25 \\
\hline MOM & & & 12 \\
\hline FG & & & 26 \\
\hline Denmark & Friis-Glamann (1958) & $1750-1800$ & 29 \\
\hline $\mathrm{AF}$ & & & 18 \\
\hline ARM & & & 7 \\
\hline MOM & & & 0 \\
\hline FG & & & 4 \\
\hline The Netherlands & Posthumus (1946) & $1750-1800$ & 49 \\
\hline$\overline{\mathrm{AF}}$ & & & 18 \\
\hline ARM & & & 18 \\
\hline MOM & & & 5 \\
\hline FG & & & 8 \\
\hline World & UNCTAD (2007) & $1960-2007$ & 52 \\
\hline$\overline{\mathrm{AF}}$ & & & 23 \\
\hline ARM & & & 12 \\
\hline MOM & & & 17 \\
\hline FG & & & 0 \\
\hline World & IMF (2008) & 1980-2008 & 45 \\
\hline AF & & & 27 \\
\hline ARM & & & 10 \\
\hline
\end{tabular}


$\underline{\text { Britain }}$

AF

ARM

MOM

FG

England

AF

ARM

MOM

FG

Britain

AF

ARM

MOM

FG
Gayer-Rostow-Schwartz (1953) 1790-1850 69

14

35

9

11

Panel 2B: Annual Data

Clark (2005) 1700-1869 36

19

7

3

7

Sauerbeck-Statist (1886-1930) 1850-1950 $\quad 41$

18

18

5

0 
Table 3 Commodity versus Manufactures Price Volatility 1700-1896

\begin{tabular}{lccc}
\hline & All Items & $\begin{array}{c}\text { Commodities } \\
\text { (COM) }\end{array}$ & $\begin{array}{c}\text { Manufactures } \\
\text { (FG) }\end{array}$ \\
\hline American Prices: Bezanson et al. & & & \\
1720-1775 & 0.084 & $0.085(101)$ & $0.082(98)$ \\
$1770-1790$ & 0.122 & $0.126(103)$ & $0.104(85)$ \\
$1784-1861$ & 0.067 & $0.073(109)$ & $0.048(72)$ \\
$1852-1896$ & 0.074 & $0.079(107)$ & $0.056(76)$ \\
& & & \\
1873-1884 & .0676 & $.0722(107)$ & $.0514(76)$ \\
1885-1896 & .0528 & $.0582(110)$ & $.0317(60)$ \\
English Prices: Clark & & & \\
1700-1819 & 0.137 & $0.143(104)$ & $0.108(79)$ \\
1820-1869 & 0.131 & $0.137(105)$ & $0.105(80)$ \\
& & & \\
British Prices: Gayer-Rostow-Schwartz & & & \\
1790-1819 & 0.056 & $0.057(102)$ & $0.051(91)$ \\
1820-1850 & 0.056 & $0.057(102)$ & $0.047(84)$ \\
& & & \\
Dutch Prices: Posthumus & & & $0.037(86)$ \\
1750-1800 & 0.043 & $0.044(102)$ & \\
Danish Prices: Friis-Glamann & & & $0.020(26)$ \\
1750-1800 & 0.076 & $0.082(108)$ & \\
\hline
\end{tabular}

Notes: The Sauerbeck-Statist series does not report data for FG, so it is not used in this table. The numbers in parentheses under the COM and FG entries are relative to the total = ALL. See text for definition of volatility. 
Table 4 Price Volatility during War, Peace and Autarky 1700-1950

\begin{tabular}{|c|c|c|c|c|c|c|c|c|}
\hline & $\begin{array}{l}\text { 1700-1775 } \\
\text { Peace }\end{array}$ & $\begin{array}{c}\text { 1776- } \\
1819 \\
\text { War }\end{array}$ & $\begin{array}{l}\text { 1820- } \\
1860 \\
\text { Peace }\end{array}$ & $\begin{array}{c}\text { 1850- } \\
1860 \\
\text { Peace } \\
\end{array}$ & $\begin{array}{c}\text { 1861- } \\
1872 \\
\text { War }\end{array}$ & $\begin{array}{l}\text { 1873- } \\
1896 \\
\text { Peace }\end{array}$ & & \\
\hline Monthly: Bezanson et al. & 0.0647 & 0.1431 & & & & & & \\
\hline Monthly: Bezanson et al. & & 0.0731 & 0.0621 & & & & & \\
\hline Monthly: Bezanson et al. & & & & 0.0743 & 0.1005 & 0.0610 & & \\
\hline Monthly: Friis-Glamann & 0.0744 & 0.0784 & & & & & & \\
\hline \multirow[t]{3}{*}{ Monthly: Posthumus } & 0.0395 & 0.0464 & & & & & & \\
\hline & 1700-1775 & $\begin{array}{c}1776- \\
1819\end{array}$ & $\begin{array}{l}1820- \\
1860\end{array}$ & $\begin{array}{l}1850- \\
1860\end{array}$ & $\begin{array}{l}1861- \\
1872\end{array}$ & $\begin{array}{l}1873- \\
1896\end{array}$ & $\begin{array}{l}1897- \\
1913\end{array}$ & 1914-1950 \\
\hline & Peace & War & Peace & Peace & Peace & Peace & Peace & $\begin{array}{c}\text { War \& } \\
\text { Autarky }\end{array}$ \\
\hline Annual: Clark & 0.1180 & 0.1475 & 0.1321 & & & & & \\
\hline Annual: Gayer-Rostow-Schwartz & & 0.0564 & 0.0559 & & & & & \\
\hline Annual: Sauerbeck-Statist & & & & 0.1251 & 0.1193 & 0.1153 & 0.1153 & 0.2205 \\
\hline
\end{tabular}

Notes: The volatility statistics are for ALL = all items. Clark's English data for 1861-1869 is ignored since the US Civil War did not directly affect England except for the cotton famine. See text for definition of volatility. 
Table 5 Modern Commodity Price Volatility 1960-2005

\begin{tabular}{ccccc}
\hline & All Commodities & Food & $\begin{array}{c}\text { Agricultural raw } \\
\text { materials }\end{array}$ & $\begin{array}{c}\text { Minerals, ores, and } \\
\text { metals }\end{array}$ \\
\hline UNCTAD Data & & & & \\
1960 & 0.0493 & 0.0553 & 0.0462 & 0.0422 \\
1965 & 0.0497 & 0.0576 & 0.0414 & 0.0436 \\
1970 & 0.0776 & 0.0867 & 0.0745 & 0.0667 \\
1975 & 0.0672 & 0.0805 & 0.0593 & 0.0527 \\
1980 & 0.0618 & 0.0752 & 0.0532 & 0.0483 \\
1985 & 0.0735 & 0.0827 & 0.0625 & 0.0698 \\
1990 & 0.0679 & 0.0822 & 0.0535 & 0.0541 \\
1995 & 0.0593 & 0.0709 & 0.0502 & 0.0453 \\
2000 & 0.0603 & 0.0711 & 0.0498 & 0.0525 \\
2005 & 0.0691 & 0.0665 & 0.0512 & 0.0848 \\
& & & & \\
IMF Data & & & & \\
1980 & 0.0701 & 0.0772 & 0.0582 & 0.0573 \\
1985 & 0.0763 & 0.0820 & 0.0602 & 0.0742 \\
1990 & 0.0713 & 0.0793 & 0.0598 & 0.0538 \\
1995 & 0.0668 & 0.0738 & 0.0610 & 0.0460 \\
2000 & 0.0634 & 0.0694 & 0.0511 & 0.0557 \\
2005 & 0.0803 & 0.0804 & 0.0608 & 0.0990 \\
\hline
\end{tabular}

Sources and Notes: UNCTAD, Commodity Price Statistics (2008) and IMF, Primary Commodity Prices Database (2008). See text for definition of volatility. 
Table 6 Volatility of US Export Prices 1880-1963

\begin{tabular}{|c|c|c|c|c|c|c|}
\hline & Total & Finished Manufactures & $\begin{array}{c}\text { Semimanufactures and } \\
\text { Crude Materials }\end{array}$ & Semimanufactures & Crude Materials & Foods \\
\hline 1880-1885 & 0.0246 & 0.0277 & 0.0234 & & & 0.0341 \\
\hline $1885-1890$ & 0.0302 & 0.0167 & 0.0174 & & & 0.0254 \\
\hline 1890-1895 & 0.0376 & 0.0254 & 0.0538 & & & 0.0405 \\
\hline 1895-1900 & 0.0366 & 0.0322 & 0.0448 & & & 0.047 \\
\hline 1900-1905 & 0.0359 & 0.0181 & 0.0633 & & & 0.0226 \\
\hline 1905-1910 & 0.0308 & 0.0117 & 0.0606 & & & 0.027 \\
\hline $1910-1914$ & 0.0279 & 0.0128 & 0.0405 & & & 0.0283 \\
\hline 1920-1925 & 0.0627 & 0.0428 & & 0.0639 & 0.1184 & 0.0921 \\
\hline 1925-1930 & 0.0295 & 0.0231 & & 0.0349 & 0.0736 & 0.0425 \\
\hline 1930-1935 & 0.0376 & 0.0505 & & 0.0392 & 0.0612 & 0.0487 \\
\hline 1935-1938 & 0.0264 & 0.0177 & & 0.0494 & 0.0505 & 0.0459 \\
\hline 1945-1950 & 0.039 & 0.0432 & & 0.0395 & 0.0358 & 0.0515 \\
\hline 1950-1955 & 0.0206 & 0.0164 & & 0.0415 & 0.0366 & 0.0366 \\
\hline $1955-1960$ & 0.0082 & 0.0073 & & 0.0347 & 0.0142 & 0.0137 \\
\hline 1960-1963 & 0.0089 & 0.0074 & & 0.0141 & 0.0176 & 0.0066 \\
\hline $1950-1963$ & 0.0125 & 0.0104 & & 0.0225 & 0.0216 & 0.0177 \\
\hline $1880-1950$ & 0.0349 & 0.0263 & & & & 0.0417 \\
\hline
\end{tabular}

Source and Notes: These volatility measures are based on the quarterly data reported in Mintz (1967: Table A-3). See text for definition of volatility. 